\title{
Correspondence
}

\section{Locum consultant posts}

\section{Dear Sirs}

The following information is submitted in support of Dr Fiona Caldicott's memorandum to Court of Electors concerning locum consultant posts (Psychiatric Bulletin, 1992, 16, 729).

A survey of the British Medical Journal Classified Advertisements section earlier this year showed that $37 \%-88 \%$ of advertised consultant posts in psychiatry were for locums. Further details are given in Table I.

TABLE I

Summary of consultant posts in psychiatry advertised over six weeks

\begin{tabular}{lccc}
\hline Week ending & $\begin{array}{c}\text { Total consultant } \\
\text { posts advertised }\end{array}$ & Locums & $\begin{array}{c}\text { Percentage } \\
\text { locums }\end{array}$ \\
\hline 21.3 .92 & 17 & 15 & $88 \%$ \\
28.3 .92 & 23 & 13 & $57 \%$ \\
4.4 .92 & 27 & 15 & $56 \%$ \\
11.4 .92 & 19 & 7 & $37 \%$ \\
18.4 .92 & 7 & 4 & $57 \%$ \\
25.4 .92 & 19 & 8 & $42 \%$ \\
\hline
\end{tabular}

A telephone survey of medical staffing offices advertising in the week ending 21.3 .92 was made three weeks later. One office was unobtainable due to staff sickness, one job had been extended from six weeks to six months, and two further full-time locum consultant posts were spontaneously mentioned as being available; thus, a total of 16 locum consultant posts in psychiatry were analysed.

Three weeks after advertising, nine of the 16 posts $(56 \%)$ remained unfilled, mostly because there had been no applicants. Of the seven filled locum posts, four were for one month or less. (Table II).

Medical staffing personnel expressed a high degree of desperation about the unavailability of locums. One wanted my name and address "so that if anything else comes up we can contact you", and one London teaching hospital tried to interest me in SHO and registrar locums even though the enquiry was about a consultant locum in forensic psychiatry indicating a poor comprehension of specialist job requirements and training. Another advertisement
TABLE II

Outcome of consultant locum posts advertised on 21.3.92, after three weeks

\begin{tabular}{|c|c|c|c|}
\hline Specialty & Duration & Filled & Unfilled \\
\hline $\begin{array}{l}\text { General } \\
\text { adult } \\
\text { psychiatry } \\
\text { (8 posts) }\end{array}$ & $\begin{array}{l}2 \text { weeks } \\
3 \text { months } \\
3 \text { months } \\
3 \text { months } \\
6 \text { months } \\
6 \text { months } \\
1 \text { month } \\
6 \text { months }\end{array}$ & $\begin{array}{l}\mathbf{x} \\
\mathbf{x} \\
\mathbf{x}\end{array}$ & $\begin{array}{l}\mathbf{x} \\
\mathbf{x} \\
\mathbf{x} \\
\mathbf{x} \\
\mathbf{x}\end{array}$ \\
\hline $\begin{array}{l}\text { Child and } \\
\text { adolescent } \\
\text { psychiatry } \\
\text { (5 posts) }\end{array}$ & $\begin{array}{c}6 \text { months } \\
6 \text { months } \\
6 \text { months } \\
3 \text { weeks } \\
3 \text { weeks }\end{array}$ & $\begin{array}{l}x \\
x \\
x\end{array}$ & $\begin{array}{l}x \\
x\end{array}$ \\
\hline $\begin{array}{l}\text { Old age } \\
\text { psychiatry } \\
\text { Forensic } \\
\text { General and } \\
\text { old age }\end{array}$ & $\begin{array}{l}6 \text { months } \\
3 \text { months } \\
2 \text { weeks }\end{array}$ & $x$ & $\begin{array}{l}\mathbf{x} \\
\mathbf{x}\end{array}$ \\
\hline Totals: & & $7(44 \%)$ & $9(56 \%)$ \\
\hline
\end{tabular}

stated "... locum bank members need not apply" they had no other applicants for their post which remained unfilled.

Not only are a high percentage of consultant vacancies advertised as locum posts, there is poor uptake of these posts. This may be affected by a variety of factors including changes in the ways that health authorities and trusts are managing their psychiatric services and senior medical staff. Clearly, there are not adequate numbers of available trained professionals to fill the required locum posts. The effects of this situation are likely to include inadequate provision of core services, hindrance of service planning and development, and an increased workload for existing staff.

The College monitors the uptake of substantive consultant posts. It may be an interesting time to start monitoring the percentage and uptake of locum consultant posts.

The Maudsley Hospital

GianetTa RaNDS 